\title{
A STUDY ON DIAGNOSTIC ACCURACY OF BIOCHEMICAL MARKERS AND TRANS-ABDOMINAL ULTRASONOGRAPHY IN COMPARISON TO MULTI-DETECTOR COMPUTED TOMOGRAPHY IN DETECTION OF ACUTE PANCREATITIS
}

\author{
Biplab Debbarma1, Kaushik Tripura ${ }^{2}$
}

${ }^{1}$ Assistant Professor, Department of Radiodiagnosis, Tripura Medical College \& Dr. BRAM Teaching Hospital, Hapania, Tripura West. ${ }^{2}$ Assistant Professor, Department of Community Medicine, Tripura Medical College \& Dr. BRAM Teaching Hospital, Hapania, Tripura West.

\section{ABSTRACT}

Acute pancreatitis is an acute, mainly diffuse, inflammatory process of the pancreas. Computed Tomography (CT) scan is the modality of choice for diagnosis of acute pancreatitis. But non-availability of Computed Tomography (CT) scan in all health facilities made detection of acute pancreatitis is problemsome.

\section{OBJECTIVES}

1. To assess the diagnostic accuracy of Biochemical Markers and Trans-Abdominal Ultrasonography in comparison to Multidetector Computed Tomography in diagnosis of acute pancreatitis. 2. To compare the findings of Trans-Abdominal Ultrasonography with Multidetector Computed Tomography.

\section{MATERIALS AND METHODS}

100 clinically suspected for acute pancreatitis patients were tested for abnormal biochemical markers, followed by examined by USG and then by MDCT in Radiodiagnosis Department of AGMC and GBP Hospital and findings were compared. Sensitivity, specificity, positive predictive value and negative predictive value were calculated.

\section{RESULTS}

The sensitivity and specificity of trans-abdominal ultrasonography was calculated as 75\% (CI 64.06\% - 84.01\%) and $100 \%$ (CI 83.16\%-100\%).

\section{CONCLUSION}

USG had similar sensitivity, but higher specificity value than serum markers (Amylase and Lipase).

\section{KEYWORDS}

Acute Pancreatitis, Trans-Abdominal Ultrasonography, Multi-Detector Computed Tomography, Sensitivity, Specificity.

HOW TO CITE THIS ARTICLE: Debbarma B, Tripura K. A study on diagnostic accuracy of biochemical markers and transabdominal ultrasonography in comparison to multi-detector computed tomography in detection of acute pancreatitis. J. Evolution Med. Dent. Sci. 2016;5(60):4181-4184, DOI: 10.14260/jemds/2016/954

\section{INTRODUCTION}

In 1992, Atlanta classification defined acute pancreatitis as "an acute inflammatory process of the pancreas with variable involvement of other regional tissues or remote organ systems associated with raised pancreatic enzyme levels in blood and/or urine."(1) Autodigestion is the cause of acute pancreatitis with annual incidence rate of 5 to 35 per 100,000 population (0.005\%-0.035\%).(2) Gallstones and alcohol abuse are the predominant cause (80\%).(3) Serum amylase and lipase are the routine investigation done in suspected cases of acute pancreatitis. Serum amylase is elevated within $24 \mathrm{hrs}$. of onset and remains so for 1-3 days. Lipase is the most specific test, one of the best single enzyme to measure.(4) Ultrasound is easily accessible, quick and detects gall bladder or common bile duct stone as the aetiological factors in

Financial or Other, Competing Interest: None.

Submission 25-05-2016, Peer Review 15-07-2016,

Acceptance 22-07-2016, Published 27-07-2016.

Corresponding Author:

Dr. Kaushik Tripura,

Assistant Professor,

Department of Community Medicine,

Tripura Medical College

\& Dr. BRAM Teaching Hospital,

Hapania, Agartala-799014, Tripura West.

E-mail: tripurakaushik@gmail.com

DOI: $10.14260 /$ jemds/2016/954 addition to features of acute pancreatitis.(5) Computed Tomography (CT) scan is the modality of choice with an accuracy of $87 \% .^{(6)}$ But non-availability of Computed Tomography (CT) scan in all health facilities detection of acute pancreatitis is problemsome. So this study is conducted with the following objectives.

\section{OBJECTIVES}

1. To assess the diagnostic accuracy of biochemical markers and Trans-Abdominal Ultrasonography in comparison to Multi-Detector Computed Tomography (MDCT) in diagnosis of acute pancreatitis.

2. To compare the findings of acute pancreatitis of TransAbdominal Ultrasonography with Multi-Detector Computed Tomography (MDCT).

\section{MATERIALS AND METHOD}

The present study was conducted from November 2011 to April 2013 in the Radio-diagnosis and Biochemistry Department of Agartala Government Medical College and GB Pant Hospital; 104 patients of clinically suspected acute pancreatitis were referred from other Clinical Departments to Radiology Department for evaluation during the study period; 100 patients were included in the study because 4 patients were refused to participate in the study. Biochemical 
markers were tested in Autoanalyzer-XL 300 in the Biochemistry Department. Serum amylase was estimated by direct substrate method and serum lipase by enzymatic method. $(7,8)$ Ultrasonography machine, model Sequina, manufacturer $\mathrm{L}$ and $\mathrm{T}$, Probe 3.5 to $5 \mathrm{MHz}$ and model SonoAce X8, manufacturer Medison, probe 2 to $5 \mathrm{MHz}$ were used for the study. All CT examinations were performed in 16 slice Multi-Detector Computed Tomography (MDCT) (Philips, Brilliance 16). All scans were viewed for the presence of acute pancreatitis, any associated aetiological factors like gallstone and its complications. Findings were compared with CT scan findings. Ethical permission was taken from Institutional Ethical Committee of Agartala Govt. Medical College. Written consent was obtained from the participants.

\section{Statistical Analysis}

The data were entered in spread sheet and analysed using SPSS 21 statistical software. Sensitivity, specificity, positive predictive value and negative predictive value were calculated.

\section{RESULTS}

\begin{tabular}{|c|c|}
\hline Demographic Variables & Frequency (n 100) \\
\hline Gender & 74 \\
Male & 26 \\
Female & $\mathbf{1 0 0}$ \\
Total & 31 \\
Age Group (In years) & 53 \\
$20-39$ & 16 \\
$40-59$ & $\mathbf{1 0 0}$ \\
60 \& above & Total \\
\hline \multicolumn{2}{|c|}{ of the Study Participants } \\
\hline
\end{tabular}

In the present study (Table No. 1), majority of the participants were male (74\%) followed by female (26\%). Majority of the participants were in the age group of 40-59 years $(53 \%)$ followed by $20-39$ years $(31 \%)$.

\begin{tabular}{|c|c|}
\hline $\begin{array}{c}\text { Probable Cause of } \\
\text { Acute Pancreatitis }\end{array}$ & $\begin{array}{c}\text { Frequency } \\
\text { (n=100) }\end{array}$ \\
\hline Alcohol & 60 \\
Gall stones & 17 \\
Alcohol \& Gall stones & 10 \\
Blunt trauma & 02 \\
Unknown & 11 \\
\hline Total & $\mathbf{1 0 0}$ \\
\hline Table 2: Distribution of the Study Participants \\
According to Probable Cause of Acute Pancreatitis \\
\hline
\end{tabular}

In this study (Table No. 2), the most probable cause of acute pancreatitis among majority of the study participants were found to be alcohol (60\%) followed by gallstones (17\%) and unknown (11\%).

\begin{tabular}{|c|c|}
\hline Biomarker Level & Frequency $(n=100)$ \\
\hline Serum Amylase & \\
\hline$>3$ Fold & 69 \\
\hline$>2$ Fold & 09 \\
\hline$>1$ fold & 16 \\
\hline WNL & 06 \\
\hline Total & 100 \\
\hline Serum Lipase & \\
\hline$>3$ Fold & 77 \\
\hline$>2$ Fold & 08 \\
\hline$>1$ fold & 08 \\
\hline WNL* & 07 \\
\hline Total & 100 \\
\hline \multicolumn{2}{|c|}{$\begin{array}{c}\text { Table 3: Distribution of the Study Participants } \\
\text { According to Biomarker Level }\end{array}$} \\
\hline
\end{tabular}

*Within normal limit

In the present study (Table No. 3), it shows that serum amylase has increased more than $>3$ folds among 69 study participants and serum lipase has increased $>3$ folds among 77 study participants.

\begin{tabular}{|c|c|}
\hline Trans-Abdominal USG & Frequency (n=100) \\
\hline Acute Pancreatitis & 60 \\
Present & 40 \\
Absent & $\mathbf{1 0 0}$ \\
\hline Total & Frequency \\
(n=100) \\
\hline Multi-Detector \\
Computed Tomography & 80 \\
\hline Acute Pancreatitis & 20 \\
Present & $\mathbf{1 0 0}$ \\
Absent & Total \\
\hline \multicolumn{2}{|c|}{ Table 4: Distribution of Study Participants } \\
According to Trans-Abdominal USG \& MDCT
\end{tabular}

In the present study (Table No. 4), it shows that in transabdominal ultrasonography signs of acute pancreatitis present among 60 study participants and that in MultiDetector Computed Tomography signs of acute pancreatitis present among 80 study participants.

\begin{tabular}{|c|c|c|c|}
\hline \multirow{2}{*}{\multicolumn{2}{|c|}{ Findings }} & $\begin{array}{c}\text { Transabdominal } \\
\text { USG }\end{array}$ & MDCT \\
\hline & & $\begin{array}{c}\text { Frequency } \\
(\%)\end{array}$ & $\begin{array}{l}\text { Frequency } \\
(\%)\end{array}$ \\
\hline & $\begin{array}{l}\text { Focal or Diffuse } \\
\text { Enlargement of The } \\
\text { Pancreas }\end{array}$ & $55(91.67 \%)$ & $60(75 \%)$ \\
\hline & $\begin{array}{l}\text { Pancreatic Gland } \\
\text { Abnormalities and } \\
\text { Inflammation }\end{array}$ & $60(100)$ & $70(87.5 \%)$ \\
\hline & $\begin{array}{l}\text { Peri-Pancreatic } \\
\text { Collection }\end{array}$ & $7(11.6 \%)$ & $16(20 \%)$ \\
\hline & $\begin{array}{l}\text { Pseudo-Pancreatic } \\
\text { Cyst }\end{array}$ & $8(13.3 \%)$ & $8(10 \%)$ \\
\hline 5. & Pancreatic Necrosis & $2(3.33 \%)$ & $2(2.5 \%)$ \\
\hline \multicolumn{4}{|c|}{$\begin{array}{l}\text { Table 5: Comparison between USG \& } \\
\text { MDCT Findings of Acute Pancreatitis }\end{array}$} \\
\hline
\end{tabular}


In this present study, (Table No. 5) focal or diffuse enlargement of the pancreas seen among 55 cases of acute pancreatitis detected by trans-abdominal ultrasonography and among 60 cases of acute pancreatitis detected by multidetector computed tomography.



Among (Table No. 6) 69 patients with elevated serum amylase more than 3 folds of normal limit, only 60 cases are diagnosed as case of acute pancreatitis by multi-detector computed tomography. Among 77 patients with elevated serum lipase more than 3 folds of normal limit, only 65 cases are diagnosed as case of acute pancreatitis by multi-detector computed tomography. The sensitivity, specificity, positive predictive and negative predictive value calculated for Serum Amylase as $75 \%$ (CI $64.06 \%-84.01 \%$ ), 55\% (CI 31.53\% $76.94 \%$ ), $86.96 \%$ (CI 76.68\% - 93.86\%) and $35.48 \%$ (CI $19.23 \%$ - 54.63\%). The sensitivity, specificity, positive predictive and negative predictive value calculated for Serum Lipase as $81.25 \%$ (CI 70.97 - 89.11\%), 40\% (CI 19.12\% 63.95\%), $84.42 \%(74.36 \%-91.68 \%)$ and $34.78 \%$ (16.38\% $57.27 \%)$.

\begin{tabular}{|c|c|c|c|}
\hline \multirow{2}{*}{$\begin{array}{c}\text { Transabdominal } \\
\text { USG }\end{array}$} & \multicolumn{2}{|c|}{$\begin{array}{c}\text { Multi-Detector } \\
\text { Computed Tomography }\end{array}$} & \multirow{2}{*}{ Total } \\
\cline { 2 - 3 } & $\begin{array}{c}\text { Acute } \\
\text { Pancreatitis } \\
\text { Present }\end{array}$ & $\begin{array}{c}\text { Acute } \\
\text { Pancreatitis } \\
\text { Absent }\end{array}$ & \\
\hline $\begin{array}{c}\text { Acute Pancreatitis } \\
\text { Present }\end{array}$ & 60 & 00 & 60 \\
\hline $\begin{array}{c}\text { Acute Pancreatitis } \\
\text { Absent }\end{array}$ & 20 & 20 & 40 \\
\hline Total & $\mathbf{8 0}$ & $\mathbf{2 0}$ & $\mathbf{1 0 0}$ \\
\hline \multicolumn{2}{|r|}{ Table 7: Cross Tabulation between } \\
\hline Transabdominal USG and MDCT Finding \\
\hline
\end{tabular}

All the (Table No. 7), 60 patients diagnosed as acute pancreatitis by trans-abdominal ultrasonography also diagnosed by Multi-Detector Computed Tomography as acute pancreatitis. The sensitivity, specificity, positive predictive and negative predictive value calculated of trans-abdominal ultrasonography was 75\% (CI 64.06\% - 84.01\%), 100\% (CI $83.16 \%-100 \%$ ), $100 \%$ (CI $94.04 \%-100 \%$ ) and $50 \%$ $(33.80 \%-66.20 \%)$.

\section{DISCUSSION}

Acute pancreatitis is one of the commonly encountered aetiologies in the emergency setting and its incidence is rising. Kinney TP et al(9) found gallstones and alcohol abuse as commonest cause in $80 \%$ of cases. Other causes are neoplasm, infection, drugs, traumatic and iatrogenic (endoscopy, postoperative).(10,11) In our study, most common causative factors were alcohol abuse and gall stone induced. Alcohol alone $60 \%$, gall stone induced $17 \%$ and both together $10 \%$. Pain is the cardinal symptom. ${ }^{(12)}$ accompanied by nausea and vomiting. In our study, most of the patients presented with abdominal pain accompanied by nausea and vomiting.

Chang JWY et al(13) reported a sensitivity and specificity of amylase at 3-fold above normal limit were $63.6 \%$ and $99.4 \%$ respectively, while sensitivity and specificity of lipase at 3fold above normal limit were $95.5 \%$ and $99.2 \%$ respectively. They concluded both are good markers, but lipase was slightly better than amylase. In our study, the sensitivity and specificity of Serum Amylase was 75\% (CI 64.06\% - 84.01\%), $55 \%$ (CI 31.53\% - 76.94\%) and for Serum Lipase was 81.25\% (CI $70.97-89.11 \%$ ), 40\% (CI 19.12\% - 63.95\%). Finstad et al(14) reported pancreatic abnormalities by USG in 45 of 48 patients $(91.7 \%)$. The classic finding of decreased gland echogenicity is present in only $44 \%$ of patients. In our study, 60 of 100 patients $(60 \%)$ had abnormal pancreatic features and in the remaining 40 patients, pancreas was normal or poorly visualized due to obesity or excessive bowel gas shadow.

\section{CONCLUSION}

In our study, Alcohol and gallstone are the commonest causes of acute pancreatitis. Raised serum lipase levels were found more than amylase level. USG had similar sensitivity, but higher specificity value than serum markers (Amylase and lipase).

\section{REFERENCES}

1. Bollen TL, van Santvoort HC, Besselink MG, et al. The atlanta classification of acute pancreatitis revisited. $\mathrm{Br} \mathrm{J}$ Surg 2008;95(1):6-21.

2. Vege SS, Yadav D, Chari ST. Pancreatitis. In: Talley NJ, Locke GR, Saito YA, eds. Gastrointestinal epidemiology. 1st edn. Malden, Mass: Blackwell 2007:221-5.

3. Topazian M, Gorelick FS. Acute pancreatitis. In: Yamada T, Alpers DH, Kaplowitz N, et al. eds. Textbook of gastroenterology. $4^{\text {th }}$ edn. Philadelphia: LippincottWilliams \& Wilkins 2003:2026-61.

4. Toskes PP, Greenberger NJ. Approach to the patient with pancreatic disease. In: Fauci AS, Braunwald E, Kasper DL, et al. eds. Harrison's principles of internal medicine. Chapter 306. 17th edn. USA: McGraw-Hill 2008:2001-5.

5. Pezzilli R, Billi P, Barakat B, et al. Ultrasonic evaluation of the common bile duct in biliary acute pancreatitis patients: comparison with endoscopic retrograde cholangio-pancreatography. Journal of Ultrasound Medical 1999;18(6):391-4.

6. Balthazar EJ. Acute pancreatitis: assessment of severity with clinical and CT evaluation. Radiology 2002;223(3): 603-13. 
7. IFCC methods for the measurement of catalytic concentrations of enzymes. Part 9. IFCC method for alpha-amylase. International federation of clinical chemistry. Clin Chem Acta 1999;281(1-2):S5-S39.

8. Moss DW, Henderson AR. Digestive enzymes of pancreatic origin. In: Burtis CA, Ashwood ER, ed. Tietz textbook of clinical chemistry. 3 rd edn. Philadelphia: WB Saunders Company 1999:p. 689-708.

9. Kinney TP, Freeman ML. Approach to acute, recurrent, and chronic pancreatitis. Minn Med 2008;91(6):29-33.

10. Lin A, Feller ER. Pancreatic carcinoma as a cause of unexplained pancreatitis: report of ten cases. Ann Intern Med 1990;113(2):166-7.
11. Banks PA, Freeman ML. Practice guidelines in acute pancreatitis. Am J Gastroenterol 2006;101:2379-400.

12. The pancreas. In: Williams NS, Bulstrode CJK, O'Connell $P$ R. eds. Bailey \& Love's short practice of surgery. Chapter 64. 25th edn. London: Edward Arnold publishers Ltd 2008:1130-53.

13. Chang JWY, Chung CH. Diagnosing acute pancreatitis: amylase or lipase? Hong Kong J Emerg Med 2011;18: 20-25.

14. Finstad TA, Tchelepi H, Ralls PW. Sonography of acute pancreatitis: prevalence of findings and pictorial essay. Ultrasound Q 2005;21(2):95-104. 